\title{
Synovial lymphoid neogenesis is associated with IL-23 expression and disease activity in rheumatoid arthritis
}

\author{
Juan D Cañete $1^{*}$, Raquel Celis ${ }^{1}$, Julio Ramírez ${ }^{1}$, Sara Marsal², Gabriela Ávila², Raimón Sanmartí ${ }^{2}$ José L Pablos ${ }^{3}$ \\ From 6th European Workshop on Immune-Mediated Inflammatory Diseases \\ Nice, France. 23-25 November 2011
}

\section{Objective}

We analyzed whether $\mathrm{LN}$ is associated with specific patterns of inflammatory cytokine expression in synovial tissue (ST), and the potential association of cytokine expression with disease activity and response to therapy.

\section{Methods}

ST samples were obtained by arthroscopy from the inflamed knee of 62 RA patients. A second biopsy was obtained after a mean of $8 \pm 5$ months of treatment in 21 patients who started TNF blockers. ST samples were immunostained with CD3 ( $\mathrm{T}$ cell), CD20 (B cell), and MECA-79 (high endothelial vessels). Total ST mRNA was extracted and gene expression of CCR7, LT-beta, IL-7, IL10, IL-17A, IL-21, IL-22, IL-23, TNF-alpha, IL-1b, and IL6 was measured by quantitative real-time PCR. Clinical and biological data were collected at inclusion and after a median follow-up of 2.3 years.

\section{Results}

28 out of 62 patients $(45.2 \%)$ had LN, which was associated with a significantly-higher expression of three key molecular markers of LN: CCR7, IL-7 and LT-beta $(\mathrm{p}<0.037, \mathrm{p}<0.038$, and $\mathrm{p}=0.009$, respectively). $\mathrm{LN}$-positive patients also had higher IL-23 $(\mathrm{p}=0.035)$ and higher DAS28 score, both at inclusion and at the end of followup ( $\mathrm{p}=0.055$ and $\mathrm{p}=0.037$, respectively). In the group of patients with ST before and after TNF blocker therapy, EULAR good response was associated with IL-10 reduction $(\mathrm{p}=0.035)$. In the entire group, EULAR response correlated with $\mathrm{IL}-1 \mathrm{~b}$ expression $(\mathrm{P}=0.014)$.

'Arthritis Unit, Rheumatology Dept., Hospital Clinic of Barcelona and IDIBAPS, Barcelona, Spain

Full list of author information is available at the end of the article

\section{Conclusion}

RA patients with LN were characterized by higher expression of key molecular markers of LN, IL-23 and higher disease activity. A significant reduction in IL-10 expression after therapy with TNF-blockers was associated with good EULAR response.

\section{Author details}

'Arthritis Unit, Rheumatology Dept., Hospital Clinic of Barcelona and IDIBAPS, Barcelona, Spain. ${ }^{2}$ Rheumatology Unit, Hospital de la Vall d'Hebró, Barcelona, Spain. ${ }^{3}$ Instituto de Investigación Hospital 12 de Octubre (I+12), Madrid, Spain.

Published: 23 November 2011

doi:10.1186/1479-5876-9-S2-P33

Cite this article as: Cañete et al: Synovial lymphoid neogenesis is associated with IL-23 expression and disease activity in rheumatoid arthritis. Journal of Translational Medicine 2011 9(Suppl 2):P33.
Submit your next manuscript to BioMed Central and take full advantage of:

- Convenient online submission

- Thorough peer review

- No space constraints or color figure charges

- Immediate publication on acceptance

- Inclusion in PubMed, CAS, Scopus and Google Scholar

- Research which is freely available for redistribution
() Biomed Central
() Biomed Central

C 2011 Cañete et al; licensee BioMed Central Ltd. This is an open access article distributed under the terms of the Creative Commons Attribution License (http://creativecommons.org/licenses/by/2.0), which permits unrestricted use, distribution, and reproduction in any medium, provided the original work is properly cited. 